\title{
2014 Retirement Choices
}

Anita Hattiangadi, Lewis G. Lee, Robert Shuford, and Aline Quester

September 2014

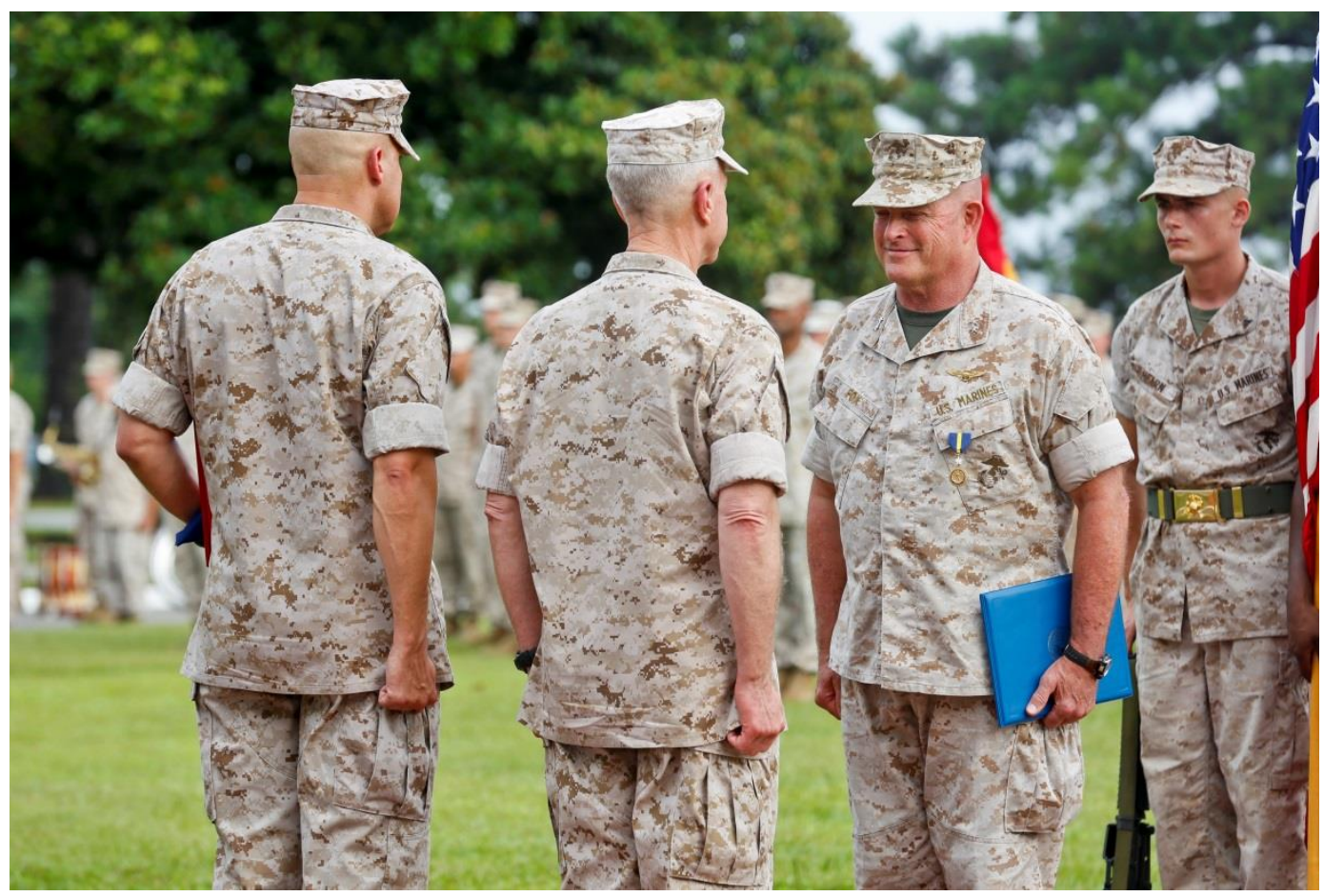




\section{Report Documentation Page}

Form Approved OMB No. 0704-0188

Public reporting burden for the collection of information is estimated to average 1 hour per response, including the time for reviewing instructions, searching existing data sources, gathering and maintaining the data needed, and completing and reviewing the collection of information. Send comments regarding this burden estimate or any other aspect of this collection of information,

including suggestions for reducing this burden, to Washington Headquarters Services, Directorate for Information Operations and Reports, 1215 Jefferson Davis Highway, Suite 1204, Arlington

VA 22202-4302. Respondents should be aware that notwithstanding any other provision of law, no person shall be subject to a penalty for failing to comply with a collection of information if it

does not display a currently valid OMB control number.

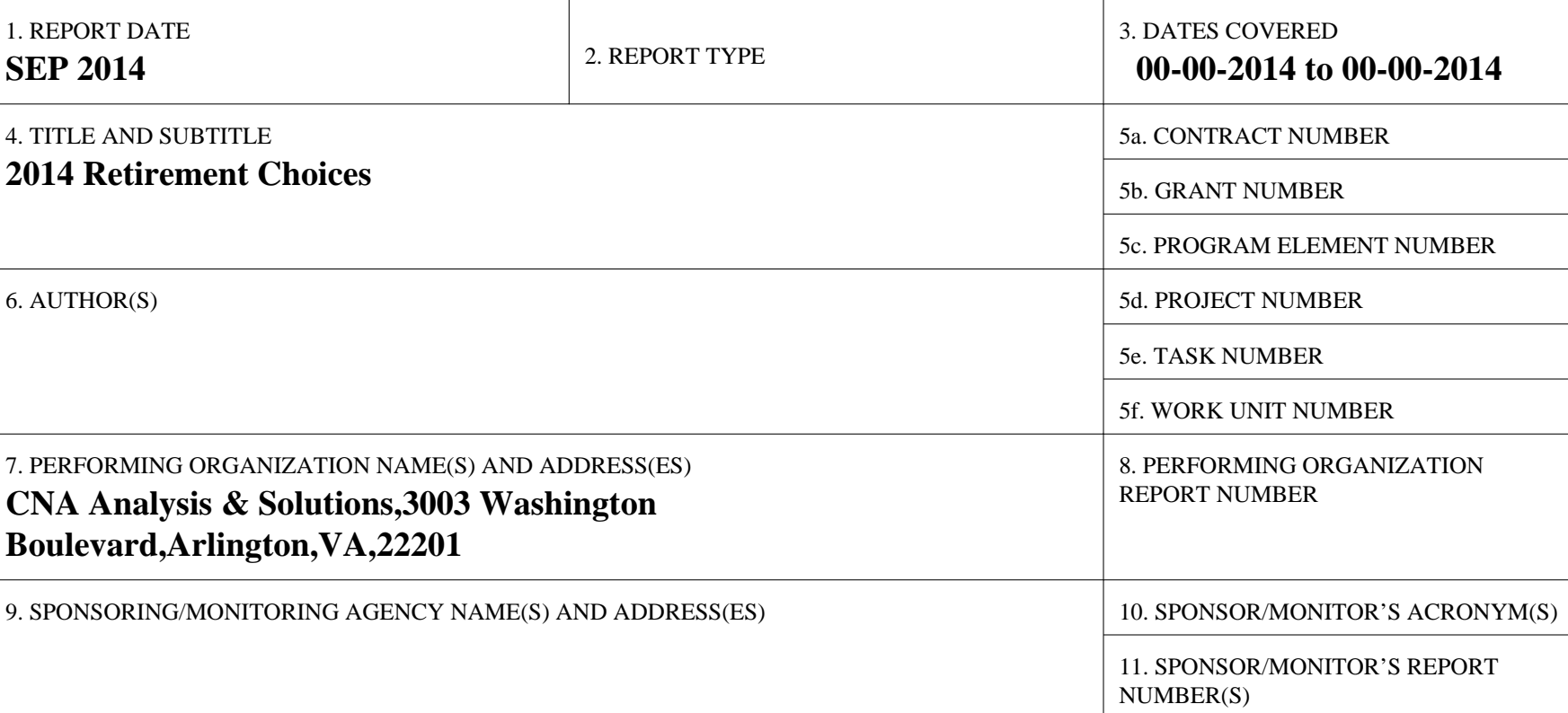

12. DISTRIBUTION/AVAILABILITY STATEMENT

Approved for public release; distribution unlimited

13. SUPPLEMENTARY NOTES

14. ABSTRACT

15. SUBJECT TERMS

16. SECURITY CLASSIFICATION OF:

\begin{tabular}{c|c|c|c|}
$\begin{array}{c}\text { a. REPORT } \\
\text { unclassified }\end{array}$ & $\begin{array}{c}\text { b. ABSTRACT } \\
\text { unclassified }\end{array}$ & $\begin{array}{c}\text { c. THIS PAGE } \\
\text { unclassified }\end{array}$ & $\begin{array}{c}\text { Same as } \\
\text { Report (SAR) }\end{array}$
\end{tabular}

\begin{tabular}{c|l}
$\begin{array}{c}\text { 18. NUMBER } \\
\text { OF PAGES } \\
\mathbf{3 0}\end{array}$ & 19a. NAME OF \\
& \\
&
\end{tabular}




\section{CNA}

This document contains the best opinion of CNA at the time of issue.

It does not necessarily represent the opinion of the sponsor.

\section{Distribution}

Cleared for Public Release, Distribution Unlimited. Specific authority: N00014-11-D-0323.

Copies of this document can be obtained through the Defense Technical Information Center at www.dtic.mil or contact CNA Document Control and Distribution Section at 703-824-2123.

Photography Credit: Commandant of the Marine Corps, Gen James F. Amos, second from left, officiates a retirement ceremony at Camp Lejeune, NC, on July 16, 2014. MajGen Raymond C. Fox, commanding general of II Marine Expeditionary Force, retired after 37 years of honorable and faithful service to the corps. (U.S. Marine Corps photo by Sgt Gabriela Garcia.)

\section{Approved by:}

September 2014

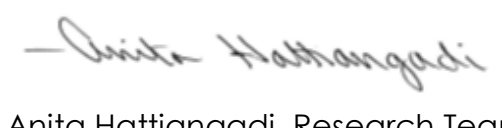

Anita Hattiangadi, Research Team Leader Marine Corps Manpower Team Resource Analysis Division 


\title{
2014 Retirement Choices
}

\author{
Dr. Aline Quester \\ SgtMaj (ret) Gary Lee \\ Ms. Anita Hattiangadi \\ Mr. Robert Shuford
}

This briefing is designed to assist Marines considering the choice between High-3 retirement and a REDUX retirement with a \$30,000 Career Status Bonus. For virtually every Marine, choosing REDUX/bonus results in a significant loss in retirement income over the course of a Marine's lifetime.

Military retirements come in the form of pensions. Pensions are risk-free, taxsheltered, inflation-adjusted annuities with options for spousal benefits (such as the Survivor Benefit Plan) on the death of the member. Such private pension provisions are very expensive, and only a few companies offer them.

But some Marines are making irrevocable choices that don't maximize their retirement incomes. This briefing addresses those choices and how decisions can be made that best suit a Marine's unique set of circumstances. 


\section{Date of Entry into Armed Forces (DEAF)}

- Obscure, but critical, date

- Determines which is your retirement plan

- Is on Statement of Leave and Earnings

- Date first enlisted/commissioned into any component of the armed forces

- Has no bearing on longevity for pay or years of service

- Should never change: not adjusted for broken time or time lost

- Other services/OSD call date DIEMS or DIEUS

Military retirement is determined by federal laws and statutes that change when Congress periodically updates them. A Marine's eligibility for a certain retirement plan depends on the very first date that he or she entered military service. It will not change for those who were in both the active and reserve components or those who transferred from another branch of the military. It is called Date of Entry into Armed Forces (DEAF), Date of Initial Entry to Military Service (DIEMS), or Date of Initial Entry to Uniformed Service (DIEUS). This date is used to determine under which plan a Marine can retire, and it can be found on a Marine's Statement of Leave and Earnings. 
What's happening now?

- Personnel are retiring under High-1

- DEAF date Sep. 7, 1980, or earlier

- Personnel are retiring under High-3

- DEAF date between Sep. 8, 1980, and Jul. 31, 1986

- Personnel are hitting 15-year-of-service point and need to make irrevocable decision on REDUX/bonus or High-3

- DEAF date Aug. 1, 1986, or later

- Aug. 2006 had first regular REDUX retirements

- Marines have to make a CHOICE

Retirement pay is based on the pay a Marine received while he or she was in the service. Those who initially entered service before Sep. 7, 1980, are retiring with their retirement pay calculated by the single highest paying year of basic pay (High1). If a Marine entered the military between Sep. 8, 1980, and Jul. 31, 1986, his or her retirement is based on the average of the 3 highest paying years of basic pay, technically the highest paying 36 months (High-3).

Those who entered service on or after Aug. 1, 1986, have the option of High-3 or a reduced retirement with a bonus paid up front (REDUX/bonus). That decision has to be made at the 15-year point and is irrevocable; a Marine CANNOT change his or her retirement plan after election.

The rest of this briefing addresses the monetary differences between these alternatives and how a Marine can make the best decision based on his or her personal situation. 
FY13 non-disability retirements: Who's retiring?

- Enlisted Marines, about 1,700

- 50 percent of them at 20 years of service

- Only 12 percent of them after $25^{\text {th }}$ year of service (about 100 make 30 years of service)

- Most are E-6s, E-7s and E-8s

- Marine Corps officers, about 700

- 30 percent at 20 years; 10 percent at $30+$ years of service

- Ranks are 0-4, 0-5, and 0-6

- Chief warrant officers

- About 130/year; 50 percent between 20 and 22 years of service

Over the last 5 years, the number of non-disability retirements has varied from 1,650 to 2,600, with 2,600 retirements occurring in FY13. For enlisted personnel, most have been gunnery sergeants and master sergeants/first sergeants, although FY13 saw a larger number of sergeants retiring than had been true in the past. Of retiring enlisted personnel, 50 percent retired with 20 years of service, 12 percent retired after 25 years of service, and 6 percent retired at 30 years of service. Thirty percent of officers retire at 20 years of service and range from major to colonel. About half of retiring warrant officers retired with 20 to 22 years of service. 


\section{REDUX/bonus vice High-3}

- REDUX/bonus

- $\$ 30,000$ at 15 years of active duty and agree to complete 20 with USMC approval

- If retire at 20 years, $\mathbf{4 0}$ percent of average base pay for highest 3 years

- Extra 3.5 percent per year for years after 20 (75 percent at 30)

- COLA at CPI rate minus 1 percentage point

- High-3

- If retire at 20 years, 50 percent of average base pay for highest 3 years

- Extra 2.5 percent per year for years after 20 (75 percent at 30)

- Full inflation protection (COLA at CPI)

This slide compares the two retirement alternatives.

Under the REDUX/bonus option, a Marine receives a \$30,000 Career Status Bonus, which is taxed, and agrees to complete at least 5 more years of active service (but must get the Marine Corps' approval for doing so). If the Marine retires at 20 years of service, he or she receives 40 percent of his or her average pay for the three highest paying years. For every year beyond 20 years of service (up to 30 years of service), the Marine receives an additional 3.5-percent increase to this amount. The retirement pay is adjusted each year to compensate for inflation (cost-of-living adjustment, or COLA) at the Consumer Price Index (CPI) rate minus 1 percent.

Under the High-3 option, a Marine who retires at 20 years of service receives 50 percent of his or her base pay. For every year beyond 20 years of service, the Marine receives an additional 2.5-percent increase to this amount (up to a maximum of 75 percent at 30 years of service). The retirement pay is adjusted each year to compensate for the full value of inflation (cost-of-living adjustment) at the CPI rate. 


\section{REDUX/bonus and High-3 features}

\begin{tabular}{|l|l|l|}
\hline Feature & REDUX/Bonus & High-3 \\
\hline $\begin{array}{l}\text { \% of basic pay } \\
\text { (highest } 36 \text { months) }\end{array}$ & 40 & 50 \\
\hline Risk & $\begin{array}{l}\text { None - backed by } \\
\text { U.S. government }\end{array}$ & $\begin{array}{l}\text { None- backed by } \\
\text { U.S. government }\end{array}$ \\
\hline Taxes & $\begin{array}{l}\text { Tax deferred until } \\
\text { retirement begins }\end{array}$ & $\begin{array}{l}\text { Tax deferred until } \\
\text { retirement begins }\end{array}$ \\
\hline Inflation Protection & $\begin{array}{l}\text { Annual COLA } \\
\text { increase } \\
\text { (CPI - 1 percentage } \\
\text { point) }\end{array}$ & $\begin{array}{l}\text { Annual COLA } \\
\text { increase } \\
\text { (CPI) }\end{array}$ \\
\hline
\end{tabular}

Both retirement choices have the following features:

- Retirement income is a percentage of the average of the highest 36 months of basic pay. There is no risk; the retirement payments are specified by law and are guaranteed by the full faith and credit of the U.S. government.

- Income is deferred compensation for which no taxes are paid until the retired pay is received. Such plans are called tax-sheltered retirement plans. The service pays into the retirement fund each year, and the fund grows while the Marine is in the service. The Marine has no tax liability for the service's contributions to the retirement fund.

- Protected against inflation. The High-3 has full inflation protection because it changes yearly with the CPI, whereas REDUX/bonus has less protection (CPI minus 1 percentage point). The value of inflation protection for retirement pay cannot be overemphasized. Most military members will be retired in about 40 years. In 40 years, one can expect prices to increase at least four times, meaning that what costs $\$ 1$ at military retirement will end up costing $\$ 4{ }^{1}$

\footnotetext{
${ }^{1}$ The CPI in 2013 was nearly 8 times the level it was in 1960. This period includes the sharp inflation in 1974 (12.3 percent), 1979 (13.3 percent), and 1980 (12.5 percent). The commonly assumed 3.5-percent inflation rate leads to a fourfold increase in prices over a 40year period.
} 


\section{How much is retirement income reduced in the} REDUX/bonus option?

- Assumptions for this briefing

- Military pay grows 3.5 percent per year until retirement

- CPI grows 3.5 percent per year

- Servicemember lives to age 79

- Enlisted are in 15-percent tax bracket; warrant officers are in 25percent tax bracket; officers are in 28-percent tax bracket

- Retirement Choice Calculator

- User can input tax rate and expected lifespan

To compare the two retirement plans, we must keep some aspects constant by making some assumptions. First, we assume that both military pay and the CPI will grow 3.5 percent each year. We also assume that the Marine lives to age 79 because the average life expectancy in the United States is approximately $79 .{ }^{2}$ For tax purposes, we assume that enlisted Marines will fall in the 15-percent tax bracket, warrant officers will fall in the 25-percent tax bracket, and officers will be in the 28percent tax bracket.

The calculator that we developed allows the user to input the appropriate tax rate and expected lifespan to customize the information to his or her personal future circumstances. The calculator provides a more refined approximation of differences between the two plans.

\footnotetext{
${ }^{2}$ The National Vital Statistics Reports show an additional 40.4 years for someone age 40, so we err on the side of caution and use an overall life expectancy of 79 years for military retirees. In a later section, we explore what happens if the servicemember lives past 79 years. See http://www.cdc.gov/nchs/data/nvsr/ nvsr62/nvsr62_07.pdf.
} 
E-7 retiring at age 38 with 20 years of service, $15 \%$ tax bracket

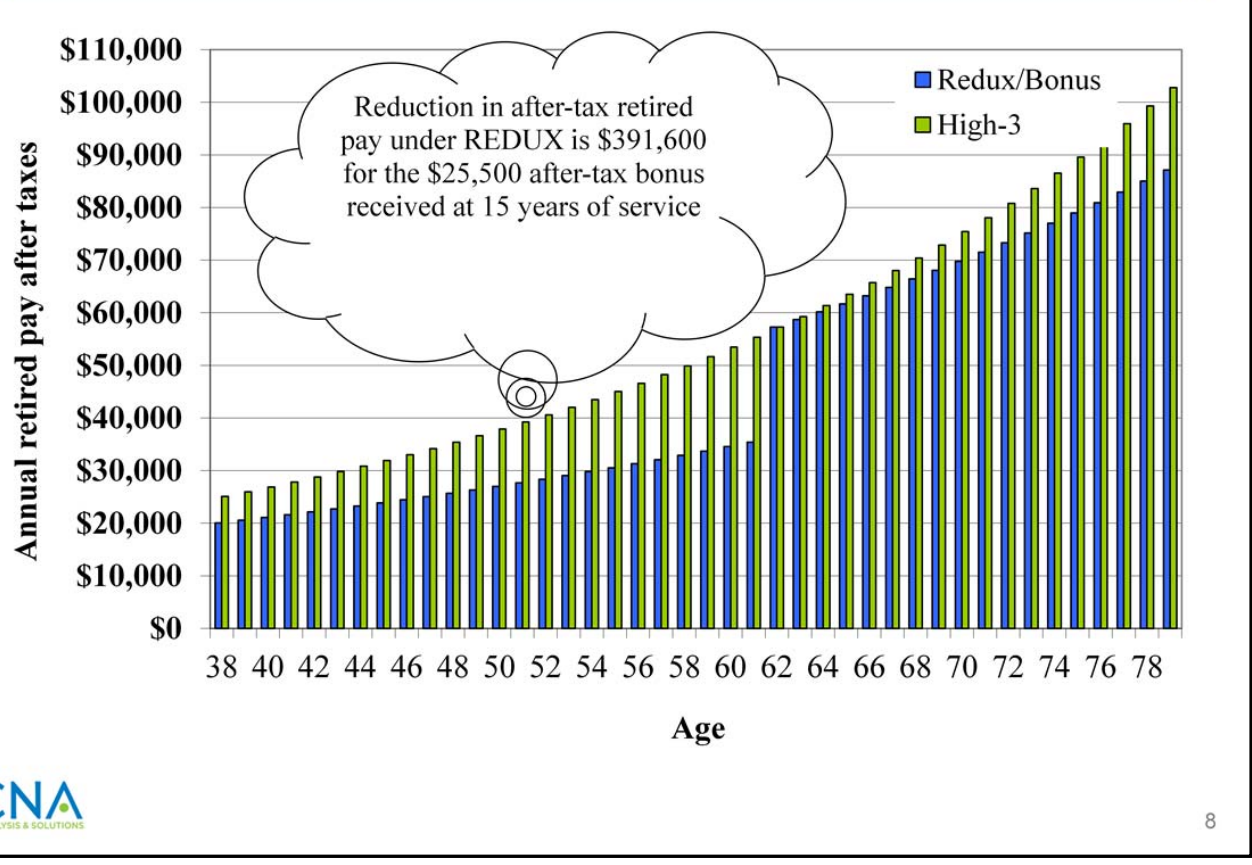

Some Marines may think that getting a lower amount of retirement income under the REDUX/bonus plan is appropriately offset by the bonus; however, over the life of a Marine, this $\$ 25,500$ (after taxes) amount is drastically smaller than the reduction in future retirement income.

For an E-7 who retires at age 38 with 20 years of service and who is in the 15percent tax bracket, the difference between retiring under High-3 and REDUX/bonus is $\$ 391,600$ over his or her lifetime, assuming that he or she lives until age 79. The design of the two plans makes them equal when the Marine is 62; however, before and after that age, the Marine receives less retirement pay under REDUX/bonus than the High-3 plan, largely because of the reduced COLA.

The higher the Marine's grade and the lower the years of service at retirement, the greater the reduction. In other words, fast-trackers who retire very early are penalized most severely. For all military personnel, however, REDUX retirement income is substantially lower than retirement income under High-3. 


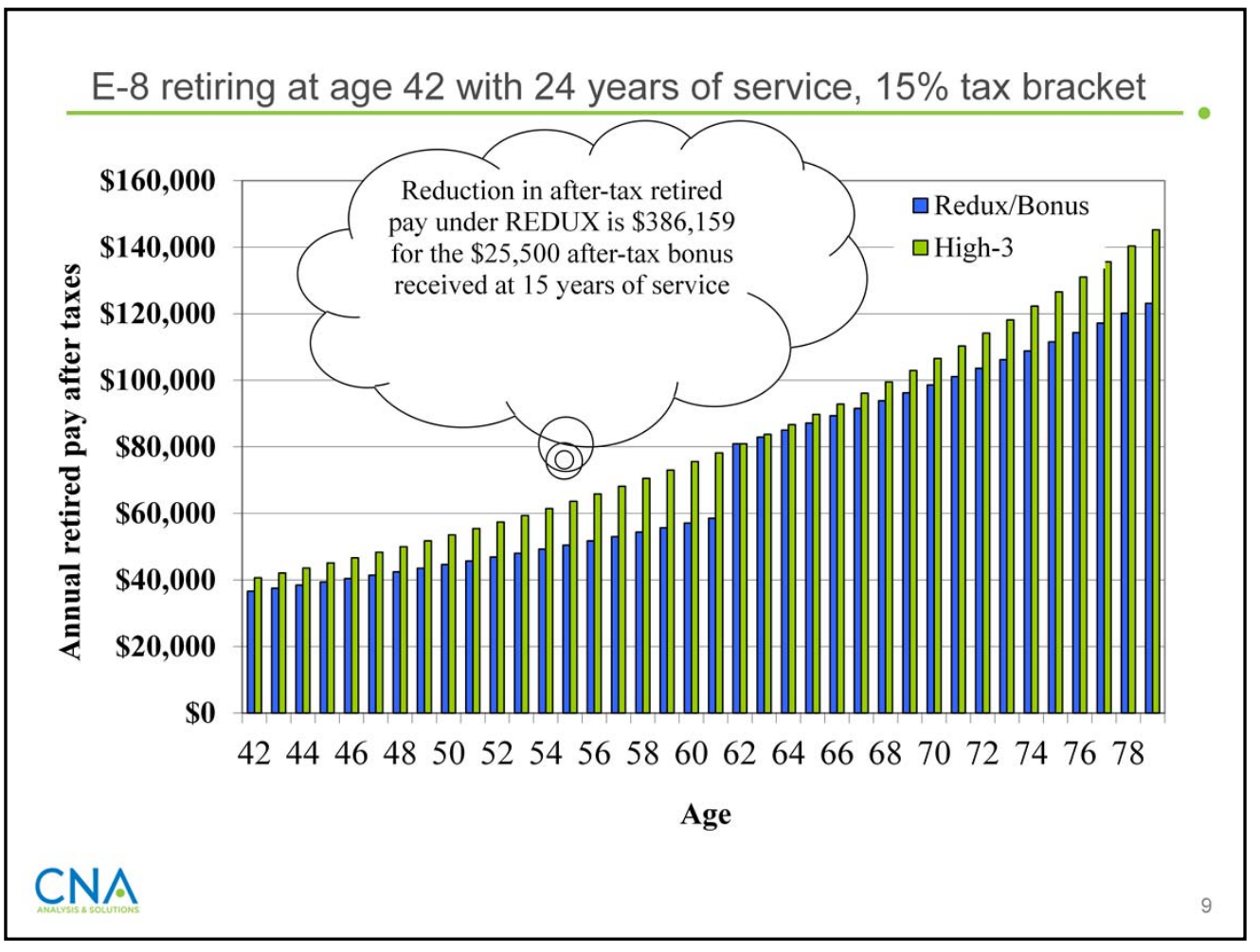

This slide shows the difference in payments for a Marine who expects to retire as an E-8 at age 42 with 24 years of service. Here, the reduction in retired pay $(\$ 386,159)$ is just a little less than that for the E-7 who retires at 38 with 20 years of service (previous slide). 
CWO-3 retiring at age 38 with 20 years of service, $25 \%$ tax bracket

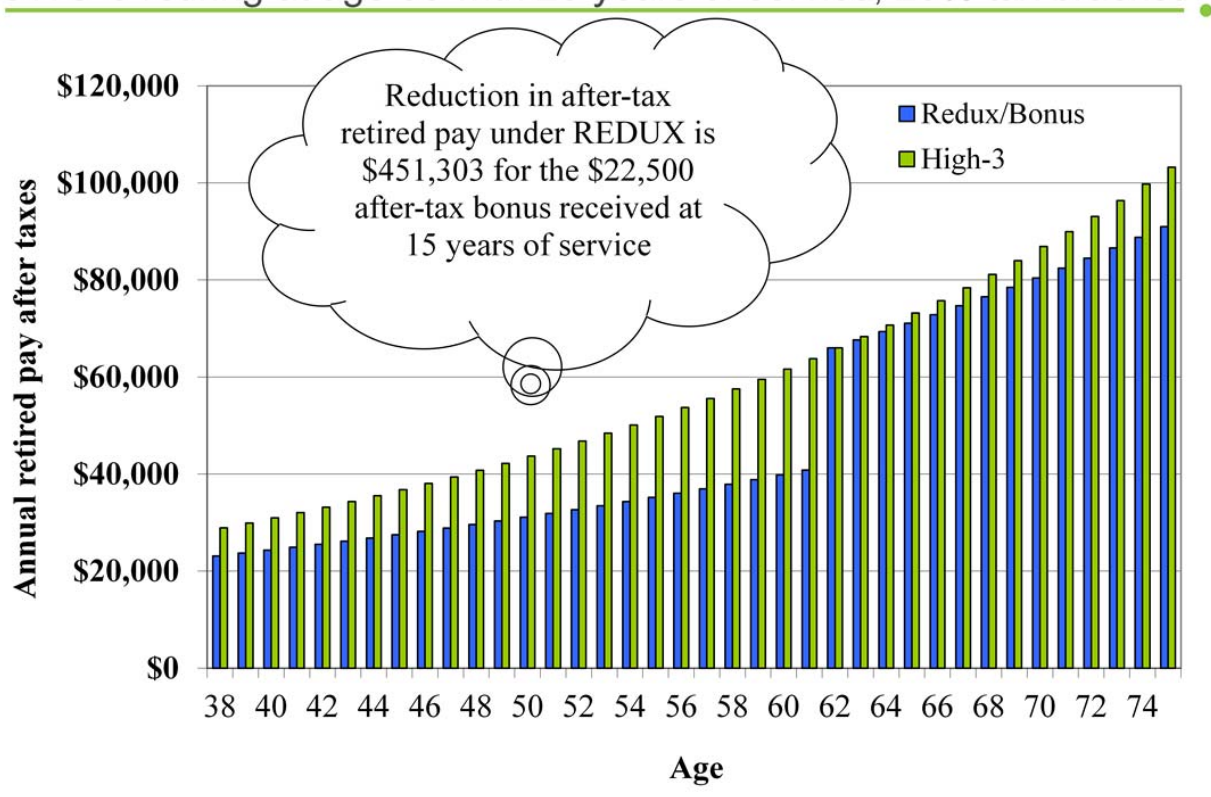

CNA

This slide shows the situation for a CWO-3 who expects to retire at age 38 with 20 years of service. Here, the reduction in retirement pay is substantially higher under REDUX/bonus $(\$ 451,303)$. 


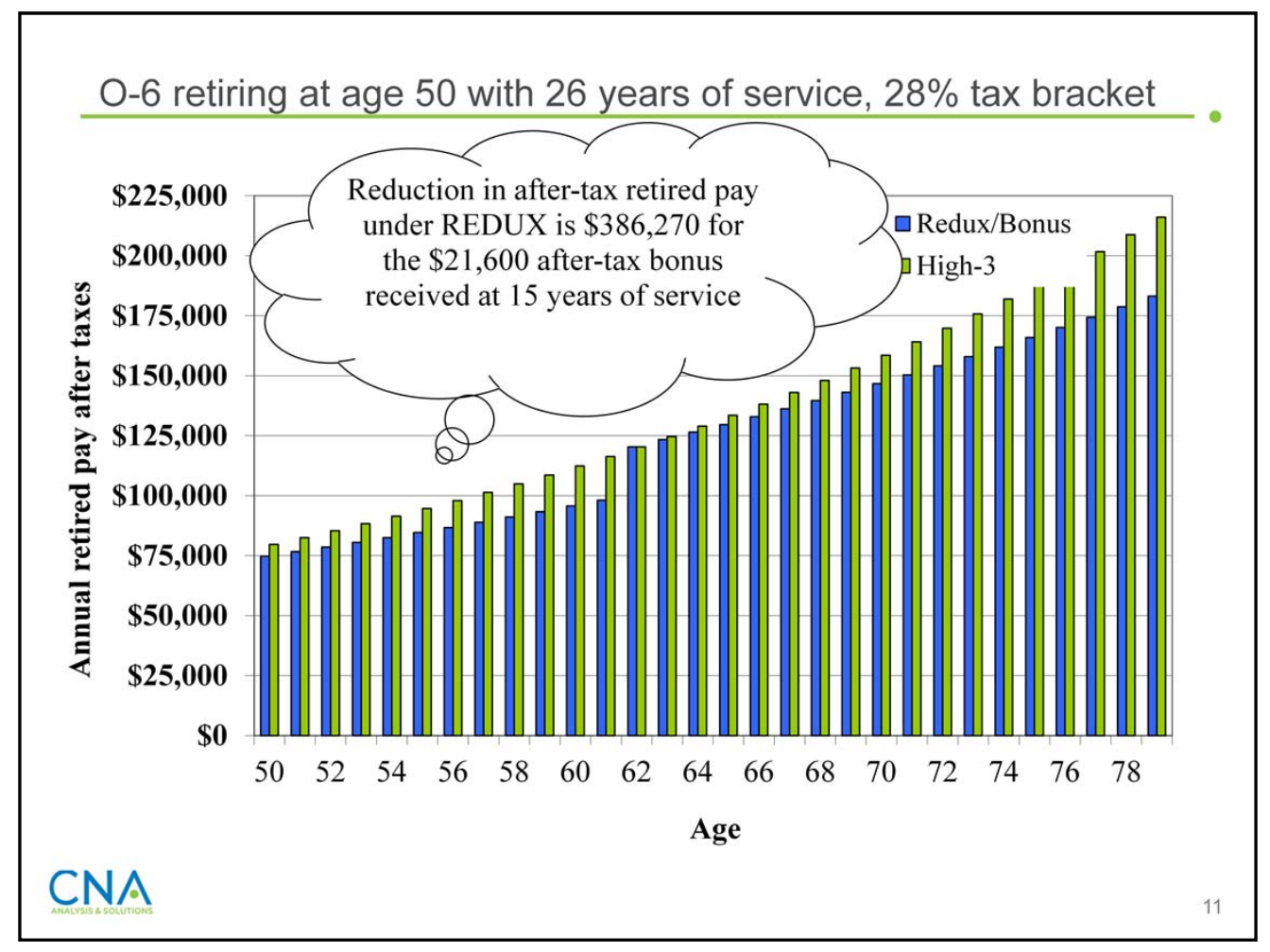

This slide shows the situation for an O-6 who expects to retire at age 50 with 26 years of service. Here the officer's retired after-tax pay is \$386,270 less under REDUX/bonus than it would have been under High-3. 
Get paid now or get paid later: How do you compare?

- Consider this cash-out as a "loan" to be paid back by smaller retirement checks in the future

- Mortgages, car loans, and credit card debt are other examples

- Use an annual percentage rate (APR) as interest rate to describe the transaction

- Peculiar repayment scheme

- Pay nothing until you retire; then pay back until death

- Earlier figures illustrated repayment amounts

Bonus-takers will get some of their retirement income early, at the 15-year-ofservice point. The best way to think about this is to consider REDUX's $\$ 30,000$ Career Status Bonus as an early cash-out of part of a Marine’s retirement pension. We can calculate how much this cash-out costs the Marine by thinking of it as a "loan" to be paid back later in the form of lower retirement checks.

This so-called loan, given at 15 years of service, is paid back over the Marine's entire retired lifetime. Most people are familiar with car loans, mortgages, and credit card debt. Car loans and mortgages have fixed loan periods, often 5 years for cars and 30 years for mortgages. Credit card debt is a little different, requiring only a minimum payment per month. We characterize all of these loans by the interest rates and interest payments attached to them.

The \$30,000 bonus has a rather peculiar payback scheme. The Marine pays nothing until retirement, pays quite a bit from the beginning of retirement until age 62, and then continues to pay back smaller amounts over the rest of his or her lifetime. The "payments" are the differences in the height of the High-3 and REDUX/bonus bars in the four previous slides. Although this payment scheme is peculiar, we can calculate the implied interest rate, or annual percentage rate (APR). 
Repayment amounts for the $\$ 30,000$ Career Status Bonus

- Retiring at 20 years of service, age 40

- \$295,352 for E-6s

- \$344,709 for E-7s

- $\$ 377,037$ for E-8s

- $\$ 431,130$ for E-9s

- \$397,262 for CWO-3s

- $\$ 438,283$ for O-4s (retirement age 42 )

- $\$ 485,610$ for O-5s (retirement age 42)

- If live to 85 years, add another $\$ 100,000$ to $\$ 175,000$

If an E-6 expects to retire at age 40 with 20 years of service and lives to age 79 , our calculations show that, by selecting REDUX/bonus at 15 years of service, the Marine:

- Pays an implicit interest rate of 13.5 percent for the cash-out (this is after tax)

- Loses \$295,352 in after-tax retirement income

- Would be required to earn at least 15.9 percent before tax each year until age 79 on the invested bonus to make up the difference between the REDUX retirement plan and the High-3 retirement plan.

If the Marine lives until age 85, the retirement income loss includes roughly another $\$ 100,000$ to $\$ 175,000$. 


\section{How do the terms compare with a 30 -year mortgage?}

- $\$ 30,000$ continuation bonus has

- Higher interest rate or APR

- Much larger repayment amounts

- Example of E-7 retiring at age 40 with 20 years of service

- $\$ 30,000$ bonus has APR of 14.8 percent and $\$ 344,709$ repayment amount

- $\$ 30,00030$-year mortgage has APR of 4.0 percent and repayment amount of about $\$ 52,000$

Even for a 9-percent, 30-year home mortgage loan—a very high interest rate by current standards — one pays back a little under three times the amount borrowed. For today's 4.0-percent mortgages, one pays back less than twice the loan amount. For the after-tax portion of the $\$ 30,000$ bonus, our calculations show that the Marine is paying back from 10 to 19 times the bonus (i.e., the amount "borrowed")! ${ }^{3}$ One might ask, "Why are the repayment amounts so large for this $\$ 30,000$ 'loan'?’

If the Marine dies at the retirement point, there is no repayment. The Marine received the $\$ 30,000$ at the 15 -year point but died before collecting any retirement monies. Most Marines, however, will live well beyond the retirement point, so one reason why repayment amounts are so large is that the terms of this financial arrangement are reduced retirement checks over the entire lifetime. ${ }^{4}$ Average life expectancy is roughly 79, and Marines (who are in better physical condition than comparably aged civilians) likely live longer and lose more money since this "loan" cannot be paid off early and has no termination point.

\footnotetext{
${ }^{3}$ All calculations are after taxes. An E-6 with 20 years of service who retires at age 42 pays back $\$ 258,943$ for the $\$ 25,500(\$ 258,943 / \$ 25,500)=10.2$; an E-9 who retires with 20 years of service at age 38 pays back 19.2 times the amount borrowed $(\$ 489,778 / \$ 25,500)$.

${ }^{4}$ We have not addressed survivor benefits in this analysis, but the reduced retirement income may make the Survivor Benefit Plan (SBP) unaffordable for some REDUX retirees.
} 
Why reject more generous High-3 and select REDUX/bonus?

- Want money now

- Car, boat, or house

- Debt repayment

- Won't live past 60 and no spouse

- Think you can do better by investing money (TSP)

Why would anyone reject the more generous High-3 retirement plan and select the bonus and associated reduced retirement payments under REDUX? There are two main reasons:

- Marines want or need money now.

- Marines think that they can do better by investing the $\$ 30,000$.

Many have immediate financial needs, and many believe that the federal government's Thrift Savings Plan (TSP) provides especially good investment opportunities. Neither of these reasons, however, should justify the REDUX/ bonus choice. Marines who want or need money now should look into other (less costly) ways to obtain money. Are there alternatives for borrowing \$30,000 that do not entail several hundred thousand dollars of interest payments? 
- What rate of return would you need to break even between REDUX/bonus and High-3?

- Put bonus in investment and each year in retirement draw out exactly the difference between the REDUX/bonus and High-3 retirement plans

- Do this until age 79

- At age 79 would have exhausted the money in the account

- Note that Marine must obtain the breakeven rate of return for every year until age 79

The breakeven interest rate is the before-tax interest rate that a Marine would have to earn to equalize compensation under the High-3 and REDUX/bonus retirement packages. For example, if the Marine put the after-tax bonus into an investment account, that investment account would have to earn the breakeven interest rate every year to generate an income equal to the yearly difference in retirement pensions. And, at age 79, the account would be exhausted. If, for only one year, the Marine earned less than the breakeven interest rate, the account would be exhausted before the Marine's death. ${ }^{5}$ The breakeven interest rates are high enough that it will be virtually impossible for anyone to break even.

\footnotetext{
${ }^{5}$ The breakeven interest rate is higher than the after-tax interest rate because taxes must be paid on investment income. The after-tax implicit interest rate times 1 minus the tax rate equals the breakeven interest rate.
} 
- Retiring at 20 years of service, age 40

- 15.9 percent for E-6s

- 17.4 percent for E-7s

- 18.2 percent for E-8s

- 19.6 percent for E-9s

- 22.7 percent for CWO-3s

- 26.9 percent for O-4s (retirement age 42)

- These rates aren't attainable

In a strong and growing economy (which is not the current economic environment), investors commonly use 10 percent to indicate average or slightly above average growth in stocks. Sustaining a 15.9-percent rate of return or higher every year during a Marine's retirement is unattainable. 
Thrift Savings Plan (TSP)

- Terrific vehicle for saving for older years

- Tax-sheltered

- Penalties for withdrawing before age $591 / 2$

- But, cashing-out the tax-sheltered High-3 to put money in tax-sheltered TSP is bizarre

- Even if you get the bonus tax free in a combat zone

- Need to earn much higher than normal returns every year to break even

- Moreover, High-3 pension is inflation-protected and risk free

Marines now can contribute pre-tax dollars to a TSP. By doing so, uniformed personnel can save additional monies for the years in which they are truly retired. However, TSPs were designed to provide savings for a member's older years, so there are tax penalties for withdrawals before age 591/2. In short, Marines should not put savings that they anticipate needing before their sixties in TSPs. (Note that, under exceptional circumstances, the tax penalties for early withdrawals can be waived.)

Retirement savings plans such as the TSP share one feature with conventional military retirement plans - the tax sheltering of pre-retirement income. Many Marines, in fact, do not seem to realize that military pensions are tax sheltered. Retirement tax sheltering means that no taxes are paid until the money is received in retirement. With military pensions, the Marine pays no taxes on the accrued benefits until the pensions are paid in retirement. TSPs involve pre-tax contributions, and taxes are not paid until the money is withdrawn. However, TSPs lack the two other important features of the High-3 retirement plan: (1) risk-free, guaranteed payments or returns and (2) full inflation protection.

The TSP offered to military members allows the member to choose the fund, or funds, in which to invest the savings. These funds differ by the level of risk or variability of the investment returns. Funds that have higher risk will have higher average returns for longterm investors, but those returns will be more variable. None of the funds, however, have inflation protection or guaranteed returns. 


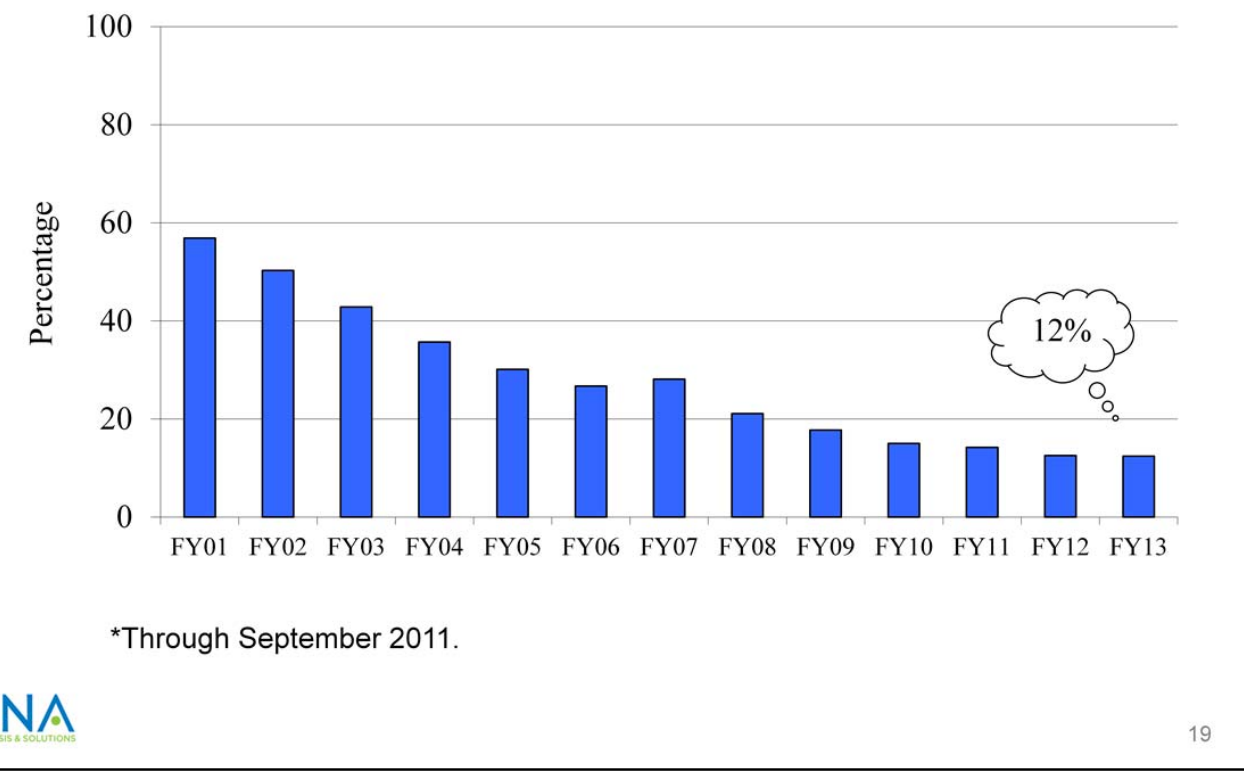

Despite the significant downsides of the REDUX/bonus choice, many Marines still choose this option every year. As of FY13, more than 24,000 Marines had made their choices. Of those who had decided:

- 29 percent of enlisted Marines chose the REDUX/bonus retirement

- 23 percent of warrant officers chose REDUX/bonus

- 6 percent of officers chose REDUX/bonus.

- In the early years, officers in grades O1E through O3E were much more likely than other commissioned officers to select the bonus. In FY13, however, the take-rates were similar.

These take-rates have fallen sharply over time. Overall, the percentage of all Marines selecting the bonus declined from 56 percent in 2001 to 12 percent in FY13. Thus, by FY13, fully 88 percent of Marines selected High-3 as their retirement plan.

The take-rates in FY13 were:

- 16 percent for enlisted Marines

- 11 percent for warrant officers

- 2 percent for officers.

Gunnery sergeants make up the largest group to face the retirement choice; their takerate for REDUX/bonus dropped from 53 percent to 14 percent in the period. 
REDUX/bonus choice gets worse each year:

Differences since 2001 are well over $\$ 100,000$ !

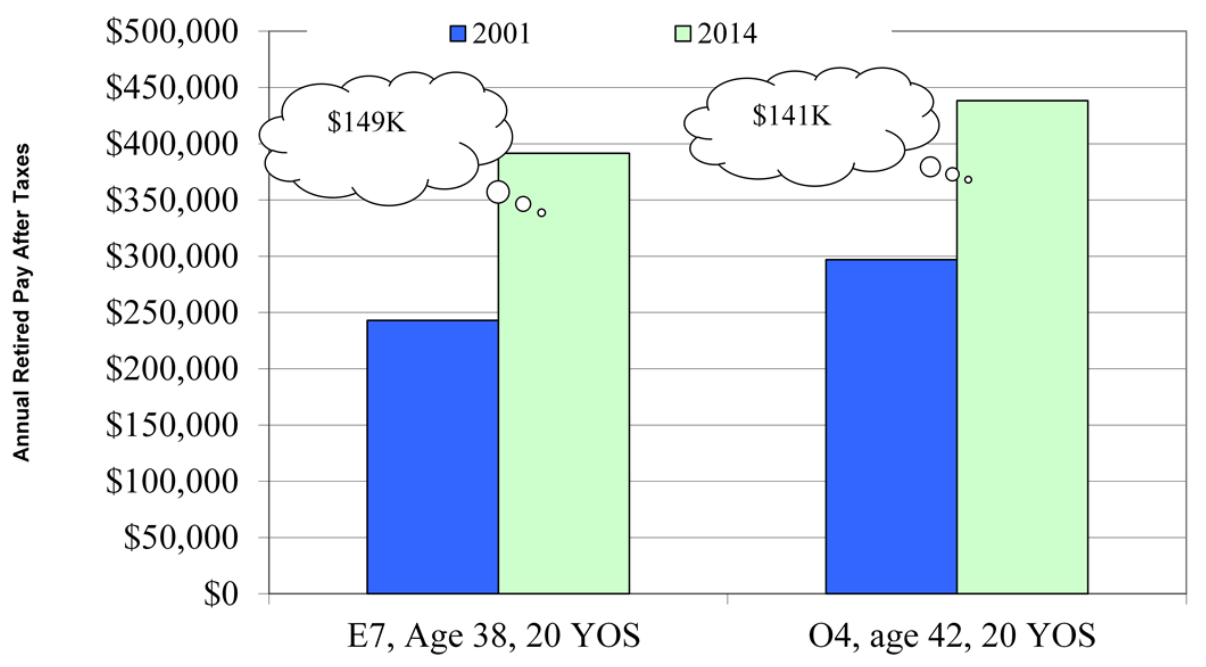

CNA

As each year passes, the difference between REDUX/bonus and High-3 retirement income increases. For example, the additional reduction in retirement income under REDUX/bonus for those making the choice in 2014 (compared with 2001) is well over $\$ 100,000$ for virtually all retirees! An E-7 who retires at age 38 with 20 years of service in 2014 loses $\$ 149,000$ more under REDUX/bonus than if he or she had retired in 2001. For an O-4, the difference between 2001 and 2014 retirement pay values is $\$ 141,000$. 
- Virtually everyone loses about $\$ 300,000$ if they select the $\$ 30 \mathrm{~K}$ bonus and REDUX retirement

- Officer take-rate is 2 percent

- Enlisted take-rate is 16 percent

- Enlisted Marines will lose as much as officers!

- Need to get the word out about the consequences of this choice

Retiring under REDUX/bonus results in lost retirement income-income that cannot be made up by investing the bonus. Enlisted Marines lose just as much money as officers under this retirement option, but only a small portion of officers take the REDUX/bonus option, compared with over a quarter of staff sergeants. Enlisted Marines need to know how much they stand to lose if they choose REDUX/bonus over High-3. 
MARADMIN 427/11

Commander's responsibility

- Ensure that all affected Marines receive appropriate counseling

- Certify that Marine electing REDUX/bonus is recommended and qualified to continue to 20 years of service

- Verify that a $\mathrm{CO}, \mathrm{XO}$, or SgtMaj witnessed election in block 13 of DD form 2839

- All Marines electing to receive REDUX/bonus must complete an online tutorial (this briefing) and present completion certificates

In an attempt to further educate its Marines, the Marine Corps has issued MARADMINs since 2007 that reinforce the commander's responsibilities. ${ }^{7}$ If a Marine chooses the REDUX/bonus, the commander must be certain that:

- He or she receives appropriate counseling about this choice

- He or she is recommended and qualified to continue to 20 years of service

- A commanding officer, executive officer, or sergeant major witnessed the election in block 13 of the DD form 2839

Any Marine electing to receive REDUX/bonus must work through an online tutorial (namely, this briefing) and present certificates of completion.

${ }^{7}$ The latest one to date is MARADMIN 427-11. 
Retirement choice CD: 2014

- Take back to your commands

- CD has:

- This briefing

- Calculators (one for big screen and one for desktop/laptop)

- Information also is on CNA's website

- Go to www.cna.org and search for "retirement choice"

CNA has developed a CD that contains this briefing along with calculators so that you can run numbers for yourself and your people. There are two versions of the calculator - one designed to be shown on a big screen monitor and one for a desktop or laptop. The CD also includes the paper that presents our findings. In addition, the information is available on CNA's website (www.cna.org); just search for "retirement choice." All of this information is for you to take back to your commands and your people. Please copy and distribute freely. 
- At the 15-year-of-service point, every Marine must choose to retire under REDUX/bonus or High-3

- REDUX/bonus provides $\$ 30,000$ in cash up front, but at a very steep penalty

- Marines lose about $\$ 300,000$ during retirement

- CNA and the Marine Corps are actively educating Marines

- Few officers take REDUX/bonus but over $1 / 4$ of E-6s do

- Developed calculator to determine loss amounts

- Provide briefings on difference in retirement options

- High-3 provides more retirement income

According to law, every Marine who entered on or after Aug. 1, 1986, has the choice to retire under REDUX/bonus or High-3. This decision is made at the 15year-of-service point and is irrevocable. Through detailed analysis, CNA has determined the loss amounts for those who choose REDUX/bonus, which is at least $\$ 300,000$ and, for some, almost $\$ 500,000$. About 2 percent of officers and 16 percent of enlisted take the REDUX/bonus retirement option.

CNA and the Marine Corps have developed several products to assist in this decision, including briefings and a retirement calculator. Educating Marines to ensure that they have the most accurate information for their personal situations is critical so that they can make informed decisions about their retirements. 


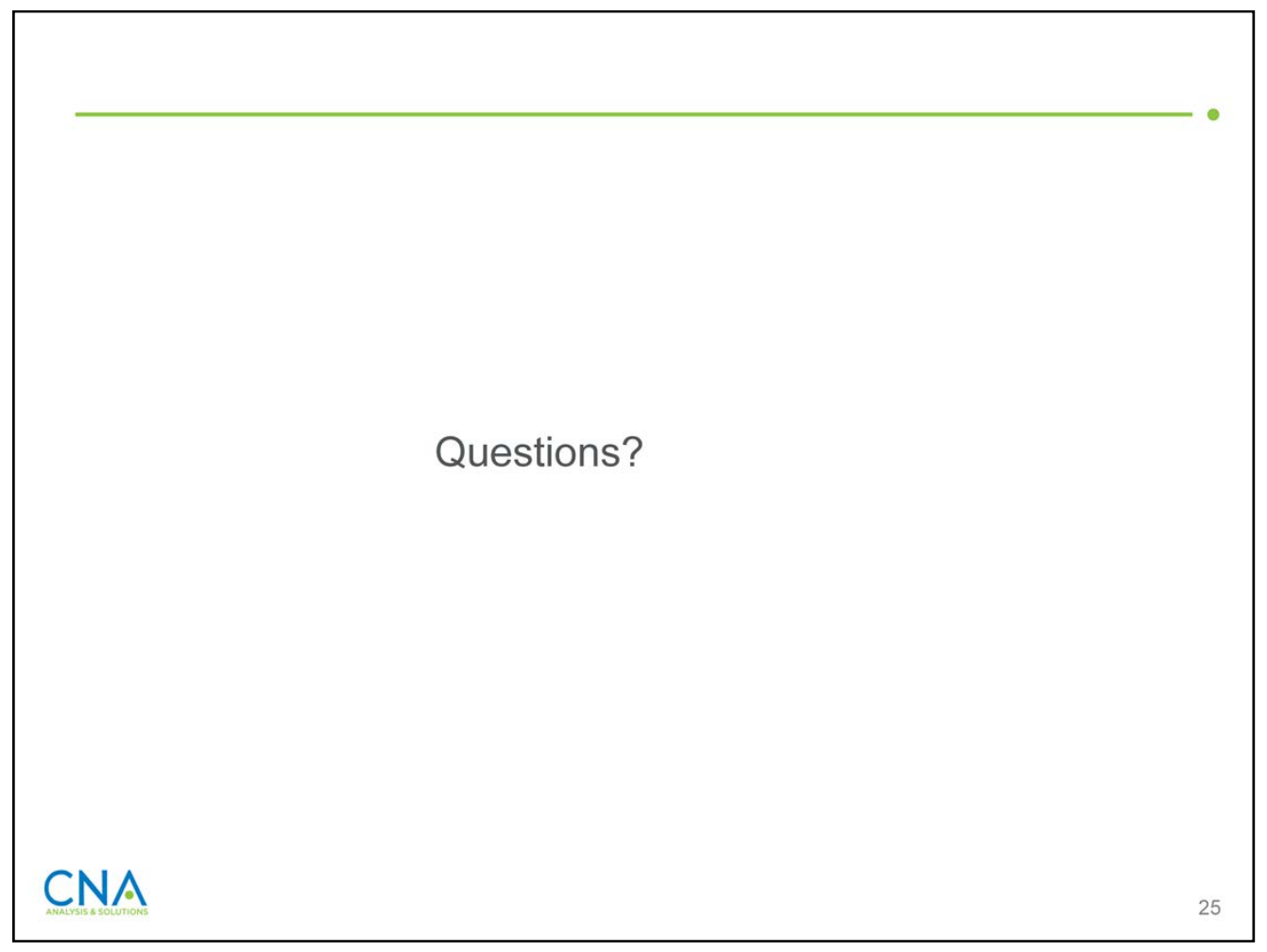

If you have questions about the content of this briefing, please contact the authors at CNA: 703-824-2000 or inquiries@cna.org. 
This page intentionally left blank. 


\section{CNA}

\section{The CNA Corporation}

This report was written by CNA Corporation's Resource Analysis Division (RAD).

RAD provides analytical services_through empirical research, modeling, and simulation-to help develop, evaluate, and implement policies, practices, and programs that make people, budgets, and assets more effective and efficient. Major areas of research include energy and environment; manpower management; acquisition and cost; infrastructure; and military readiness.

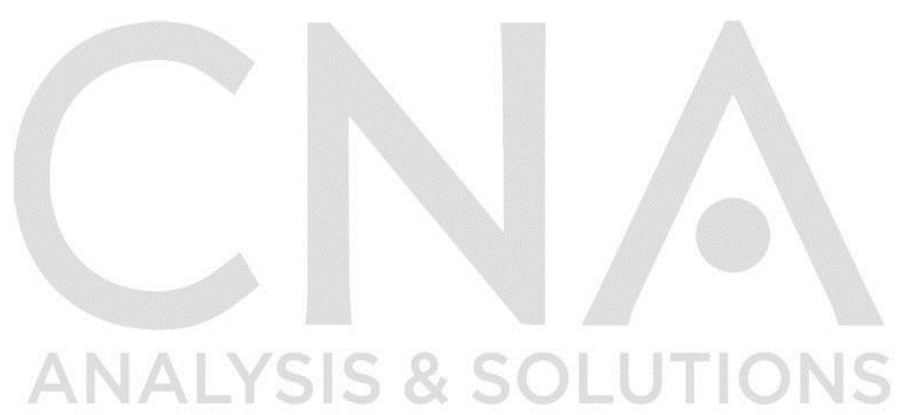




\section{DAB-2014-U-008572-Final}

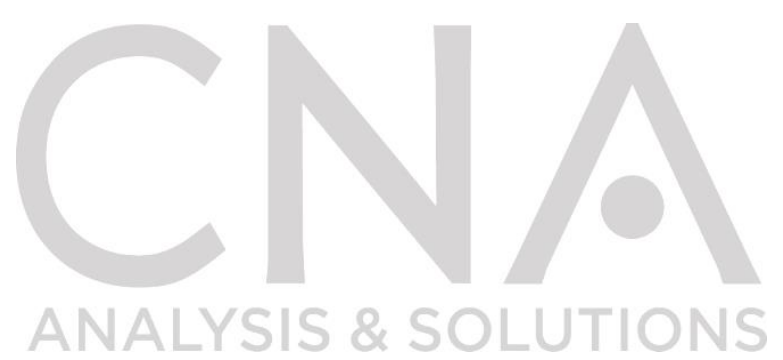

CNA Corporation is a not-for-profit research organization that serves the public interest by providing in-depth analysis and result-oriented solutions to help government leaders choose the best course of action in setting policy and managing operations.

Nobody gets closer-

to the people, to the data, to the problem. 